\title{
DOES THE SUPREME COURT FOLLOW THE ECONOMIC RETURNS? A RESPONSE TO A MACROTHEORY OF THE COURT
}

\author{
ERNEST A. YOUNG $\dagger$ \\ ERIN C. BLONDEL ††
}

INTRODUCTION

Finley Peter Dunne's fictional political sage, Mr. Dooley, famously said that the Supreme Court "follows th' iliction returns." In their contribution to this Symposium, Thomas Brennan, Lee Epstein, and Nancy Staudt argue instead that Supreme Court decisions track macroeconomic indicators. ${ }^{2}$ Drawing on evidence that voters tend to vote for the government in a strong economy or during economic crises but vote against the government during more moderate economic slumps, ${ }^{3}$ Professors Brennan, Epstein, and Staudt hypothesize that judges do the same. ${ }^{4}$ Our interlocutors have tested this hypothesis by analyzing the national government's fortunes in tax cases decided between 1912 and 1929, a period of "ordinary" economic upswings and downturns, and between 1930 and 1940,

Copyright (C) 2009 by Ernest A. Young and Erin C. Blondel.

$\dagger$ Professor of Law, Duke University School of Law. Harvard Law School, J.D. 1993; Dartmouth College, B.A. 1990.

$\dagger^{\dagger}$ Duke University School of Law School, J.D. expected 2009; Oxford University, M.St. 2006; University of Notre Dame, B.A. 2005.

This Response expands on remarks presented at the Duke Law Journal Conference on Measuring Judges and Justice, held on February 6, 2009. We are grateful to the conference's organizers for inviting us to participate, to Thomas Brennan, Lee Epstein, and Nancy Staudt for providing food for thought, to Richard Schmalbeck and Larry Zelenak for explaining earlytwentieth-century tax policy to us, and to Jonathan Williams for helpful comments on the manuscript.

1. Finley PETER DunNe, Mr. DOOLEY's OPInIONS 26 (1901).

2. Thomas Brennan, Lee Epstein \& Nancy Staudt, Economic Trends and Judicial Outcomes: A Macrotheory of the Court, 58 DUKE L.J. 1191, 1194 (2009).

3. Id. at $1191-92$.

4. Id. at 1194 . 
during the Great Depression. These data appear to support their hypothesis: In the initial period, the government tended to win more of its tax cases during upswings and lose more during downturns. During the Depression, the government won considerably more tax cases than it lost. ${ }^{5}$

Like much of the empirical literature this conference addresses, Professors Brennan, Epstein, and Staudt have demonstrated a correlation between factors that most would consider extralegal and the outcomes of judicial decisions. Unlike the greater part of that literature, Brennan, Epstein, and Staudt do not call those factors "political"-rather, they distinguish their "macrotheory" of the Supreme Court from both the conventional legal model and the attitudinal model of judicial behavior, ${ }^{6}$ which posits that judges vote to vindicate their political and policy preferences. ${ }^{7}$ Nonetheless, this economic "macrotheory" raises the same basic question that underlies this conference, not to mention the empirical project as a whole: What can empirical demonstrations of this sort teach about judges and the law?

The question is significant on a number of levels. Empirical analysis of judicial behavior is a growth industry in the legal academy, but it also seems fair to say that the field remains in its infancy. As our colleague Jack Knight's contribution to this conference suggests, ${ }^{8}$ it is a good time to be asking basic questions about what sort of hypotheses empiricists ought to be testing and how these research projects ought to relate-if at all-to traditional legal scholarship. More broadly, this sort of research has the potential to deepen our understanding of how the law works and, possibly, to increase the predictability of judicial outcomes-a basic aspect of the rule of law. ${ }^{9}$ But a downside risk exists as well: empiricists frequently posit that judges decide cases based on motivations, such as raw political preference or economic self-interest, that most participants in the

5. Id. at 1196 .

6. Id. at $1204-07$.

7. See generally Jeffrey A. Segal \& Harold J. Spaeth, The Supreme Court AND THE ATtitudinal Model Revisited (2002) (developing the attitudinal model of judicial behavior).

8. Jack Knight, Are Empiricists Asking the Right Questions About Judicial Decisionmaking?, 58 DUKE L.J. 1531 (2009).

9. See Richard H. Fallon, Jr., "The Rule of Law" as a Concept in Constitutional Discourse, 97 Colum. L. REV. 1, 8 (1997) (describing the core elements of the "Rule of Law" as including "the capacity of legal rules, standards, or principles to guide people in the conduct of their affairs" so that people can "understand the rule and comply with it"). 
legal community would consider profoundly illegitimate. Although we think that conventional thinking about law incorporates a far greater role for politics and economics than empiricists typically imagine, the project of reducing law entirely to these factors is likely to generate a great deal of hostility. ${ }^{10}$ This Symposium, and hopefully our contribution to it, is an effort to prevent empiricists and lawyers from talking past one another.

Although they acknowledge that their study is preliminary, Professors Brennan, Epstein, and Staudt make bold claims about the implications of their findings. First, they conclude that "the Justices believe they have a role to play in assuring national economic prosperity and growth." "Second, they "challenge the conventional belief that the Court maintained a strong and unambiguous bias against President Roosevelt's administration prior to the announcement of the Court-packing plan." ${ }^{12}$ Finally, they claim that their findings "may help explain Supreme Court votes in the postWorld War II era and, at the same time, forecast upcoming votes in the context of the serious national economic decline that began in 2008." $" 13$

We are skeptical that their data support these larger assertions. In this Response, we probe each of these conclusions. We argue in Part I that no evidence shows that the Justices deliberately try to affect the economy and that whether the Justices act consciously or unconsciously is an important point that Professors Brennan, Epstein, and Staudt fail to address. Part II offers a more nuanced view of the Court's activity during the Roosevelt administration. Although Brennan, Epstein, and Staudt have shown that the Court favored the government in tax cases, we argue that conventional legal analysis can offer different-and perhaps more accurate-explanations for their findings. In Part III, we argue that empirical data alone cannot necessarily predict or explain Supreme Court behavior; without probing why the Justices favor the government-an issue legal analysis can illuminate-empiricists can only guess why the Court did

10. See, e.g., Michael Boudin, Response, A Response to Professor Ramseyer, Predicting Court Outcomes Through Political Preferences, 58 DUKE L.J. 1687, 1688 (2009) ("[T]o call judges' subsequent choices in public policy cases 'political' is mere provocation.”).

11. Brennan, Epstein \& Staudt, supra note 2, at 1196.

12. Id.

13. Id. 
what it did in particular prior decisions or predict what will happen in individual future cases.

Finally, we suggest in Part IV how our interlocutors might refine their study to better assist legal scholars, lawyers, and judges. Our goal is to provide constructive avenues for further research. Professors Brennan, Epstein, and Staudt have shown an interesting correlation between economic conditions and Supreme Court decisions (at least in the tax area). Some explanation-economic, political, or legal-must exist for their findings. We have attempted to suggest some refinements to the research design that may illuminate the relationship between judicial decisions and the economy and enhance the predictive value of their model.

\section{THE COURT'S ROLE IN SHAPING ECONOMIC POLICY}

At the outset, it is important to note the strength of Professors Brennan, Epstein, and Staudt's claim. They argue that "rational Justices will look to the economy as a signal of policymaking competence in the elected branches of government and will use their decisionmaking power to support (or impede)" legislative or executive policies. ${ }^{14}$ According to Brennan, Epstein, and Staudt, Justices "believe they have a role" in shaping economic prosperity. ${ }^{15}$ This means that

judicial refusal to implement perceived policy failures could work to limit possible damage to the economy, thereby advancing the interests of the Justices. Similarly, in times of crisis, we simply argue that the Court's progovernment bias will assist Congress and the president in the recovery effort, again promoting the Justices' interests in economic growth and stability.

Brennan, Epstein, and Staudt seem to argue that Justices deliberately vote to punish, reward, or assist the government depending on the state of the economy. They have concluded, not that judicial decisions simply correlate with economic trends, but that a causal link exists because the Justices purposely decide cases to shape the economy, albeit at the margins.

This interpretation implicitly rejects a less drastic-and longaccepted-possible explanation of their data that factors such as

\footnotetext{
14. Id. at 1203 (emphasis added).

15. Id. at 1196 .

16. Id. at 1203 .
} 
external events unconsciously influence judicial decisionmaking. We have already cited Mr. Dooley's observation that the Supreme Court follows electoral returns ${ }^{17}$-an observation that may well reflect unconscious deference to the political zeitgeist rather than deliberate efforts by the Justices to accommodate political trends. Legal realism similarly observed that judges' environment and background can unconsciously sway their decisions. ${ }^{18}$ Since the advent of empirical literature on judicial behavior, many commentators have argued that unconscious influences affect judges' decisions. For example, Professor Dan Kahan has invoked cognitive theory to show that influences-such as economic conditions-unconsciously shape judicial decisions. ${ }^{19}$ Justice Holmes made the same point a bit earlier:

The felt necessities of the time, the prevalent moral and political theories, intuitions of public policy, avowed or unconscious, even the prejudices which judges share with their fellow-men, have had a good deal more to do than the syllogism in determining the rules by which men should be governed. ${ }^{20}$

Scholars have applied the notion that judges act based on unconscious predispositions to a variety of legal contexts. ${ }^{21}$

We invoke Justice Holmes in part to show that morality, views of good policy, unconscious prejudices, and political preferences have

17. See supra note 1 and accompanying text.

18. For example, Professor Jerome Frank, in his classic discussion of what factors drive judicial decisionmaking, argues that judges decide based on "a 'hunch' as to what is fair and just or wise or expedient" that emerges from "[t]he effect of innumerable stimuli on what is loosely termed 'the personality of the judge." Jerome Frank, What Courts Do in Fact, 26 ILL. L. REV. 645, 655 (1932). Frank contends, as an example, that judges hearing testimony develop a hunch as "a composite reaction of a multitude of responses to the stimuli set up by witnesses-stimuli which encounter the judge's (or jury's) biases, 'stereotypes,' preconceptions, and the like." Id. at 656.

19. See Dan M. Kahan, "Ideology in" vs. "Cultural Cognition of" Law: What Difference Does It Make? 7 (Yale Law Sch. Pub. Law \& Legal Theory Research Paper Series, Research Paper No. 180, 2008), available at http://ssrn.com/abstract=1111865 ("Judges, like everyone else,...gravitate toward the factual beliefs that are most congenial to their defining commitments.").

20. Oliver Wendell Holmes, The Common Law 1 (Mark DeWolfe Howe ed., Harv. Univ. Press 1963) (1881); see also RICHARD A. Posner, How Judges THINK 93-121 (2008) (agreeing that judges' unconscious world views shape their jurisprudence).

21. E.g., Kevin M. Clermont \& Theodore Eisenberg, Litigation Realities, 88 CORNELL L. REV. 119, 153 (2002) (arguing that appellate judges' unconscious biases may lead them to discount harms to plaintiffs); John F. Pfaff, The Continued Vitality of Structured Sentencing Following Blakely: The Effectiveness of Voluntary Guidelines, 54 UCLA L. REV. 235, 283-84 (2006) (arguing that voluntary sentencing guidelines work because they help judges form unconscious expectations about reasonable sentences). 
long been part of the legal profession's own conventional account of judicial decisionmaking. Professors Brennan, Epstein, and Staudt contrast their macroeconomic theory with the following "legal model" of judging:

In the legal model, the Court's responsibility is to ensure that government policies comply with the mandates of relevant federal laws and, absent a legal breach, the Court will uphold the government activity as entirely legitimate. The legal model, in its most extreme form, gives no consideration to the individual views of the Justices or to national political, economic, or cultural trends, unless they are somehow embedded into the law through the majoritarian process. ${ }^{22}$

It is one thing to posit this impoverished account of judicial decisionmaking as an archetype and quite another to suggest that anyone in the profession or the legal academy thinks this is how judges actually decide cases. Much of the debate about formalism in public law, for example, has concerned how to formulate legal principles in such a way as to minimize judicial discretion and thus constrain judges from following their preferences. ${ }^{23}$ The common law tradition, on the other hand, has often celebrated the open texture of legal rules as allowing independent judges to adapt the law to changing policy imperatives. ${ }^{24}$ But no one thinks these influences can be eliminated entirely. By positing a "legal model" that is alien to actual legal discourse, our interlocutors-and much of the empirical literature-undermine their ability to contribute to the debates that actually are going on.

The strong dichotomy between a "legal" and an "economic" model of judging also ignores the extent to which conventional legal analysis may incorporate economic considerations. The state of the economy may be legally relevant to the decision of cases. An economic crisis, for example, may create compelling governmental interests that figure importantly in the resolution of cases. In the Depression-era case Home Building \& Loan Ass'n v. Blaisdell, "emergency powers" arguments based on the economic crisis

22. Brennan, Epstein \& Staudt, supra note 2, at 1206.

23. See, e.g., Antonin Scalia, The Rule of Law as a Law of Rules, 56 U. CHI. L. REV. 1175, 1179-87 (1989).

24. See, e.g., Benjamin N. Cardozo, The Nature of the Judicial Process 178-79 (1921).

25. Home Bldg. \& Loan Ass'n v. Blaisdell, 290 U.S. 398 (1934). 
influenced the Court's decision to uphold state mortgage legislation against a Contracts Clause challenge. ${ }^{26}$ Many legal rules balance important interests, and an economic crisis may create stronger regulatory interests than the government would enjoy in ordinary times. Likewise, many statutes have emergency provisions that may significantly increase the government's chances of prevailing when economic conditions provide a predicate for their invocation. ${ }^{27}$ Professors Brennan, Epstein, and Staudt thus fall into a similar trap to the attitudinalists, who postulate an equally sharp dichotomy between "legal" and "political" bases of decision. ${ }^{28}$ Just as the law often incorporates political values such as federalism or concern for human dignity, ${ }^{29}$ it similarly sometimes incorporates economic considerations into conventional legal analysis. Any effort to test the relative power of "legal" and "economic" or "political" explanations must grapple with the substantial overlap between these categories of explanation in practice. ${ }^{30}$

We have no interest in denying that pure legal principles leave some room for judicial discretion, or that preferences about politics and policy sometimes fill that space. We have yet to be convinced, however, by Professors Brennan, Epstein, and Staudt's stronger claim that Justices intentionally vote to promote preferred economic conditions. Our interlocutors have provided little evidence to support that thesis. For example, in her seminal work with Jack Knight, The Choices Justices Make, ${ }^{31}$ Professor Epstein supports the claim that Justices behave strategically with internal Court memoranda documenting bargaining and other strategic behavior affecting the content of judicial opinions. ${ }^{32}$ Her article with Professors Brennan and

26. Id. at 441-42.

27. E.g., International Emergency Economic Powers Act, 50 U.S.C. $\$ \S 1701-06$ (2006).

28. SEGAL \& SPAETH, supra note 7, at 48-85, 86-97 (describing the authors' version of the legal and attitudinal models of judicial behavior).

29. See, e.g., Ernest A. Young, Just Blowing Smoke? Politics, Doctrine, and the Federalist Revival After Gonzales v. Raich, 2005 SUP. CT. REV. 1, 14-15, 18-20.

30. To show, as Professors Brennan, Epstein, and Staudt seem to claim, that economic factors are an extralegal influence on judicial decisionmaking, they would need to eliminate from their dataset those cases in which economic conditions were legally relevant. See Brennan, Epstein \& Staudt, supra note 2, at 1206 (reasoning that "macroeconomic trends are completely irrelevant to the decisionmaking process" in the legal model).

31. LeE EPSTEIN \& JACK KNIGHT, THE ChOICES JustiCES MAKE (1998).

32. E.g., id. at 32 tbl.2-2 (showing the nature and number of suggestions Justices raised in circulated bargaining memoranda in a random sample of 1983 term cases); $i d$. at 74 tbl.3-2 (indicating the number of cases in which Justices circulated memoranda containing explicit bargaining statements during the 1983 Term); $i d$. at 91 tbl.3-5 (showing the number of Chief 
Staudt, however, provides no similar documents showing that Justices weigh economic concerns when deciding cases.

Nor do other participants in the legal system act as though the Justices consider economic outcomes. If the state of the economy really influences Justices — and particularly if the Justices actively seek an economic policymaking role-one would expect participants in the legal system to talk about it. One would expect to see macroecononomic arguments-by which we mean arguments about the general state of the economy, not consequentialist claims about the effect of ruling a particular way on a particular issue ${ }^{33}$-featured prominently in briefs to the Court. Likewise, one would expect a great deal more focus on economic views and acumen during the vetting and confirmation processes for new Justices. It remains possible that the Justices consciously vote to affect economic policy but successfully conceal that fact from their clerks, legal professionals, and the public. But we await direct evidence of this phenomenon.

This disagreement is more than an issue of semantics. Like attitudinalists, Professors Brennan, Epstein, and Staudt are contending that judges make decisions based on policy preferences (according to their model, economic policy preferences) rather than the law. ${ }^{34}$ But without any evidence that Justices or lawyers acknowledge that Justices are trying to affect the economy, this

Justice Burger's attempts to manipulate the agenda in conference discussions during the 1983 Term).

33. The latter sort of argument is extremely common. See, e.g., Boumediene v. Bush, $128 \mathrm{~S}$. Ct. 2229, 2294 (2008) (Scalia, J., dissenting) (arguing that the Court's decision, allowing habeas corpus challenges to detention of enemy combatants detained abroad, "will almost certainly cause more Americans to be killed"); Brief for Petitioner at 41-51, Wyeth v. Levine, No. 061249 (U.S. May 28, 2008), available at http://www.abanet.org/publiced/preview/briefs/pdfs/0708/06-1249_Petitioner.pdf (arguing that allowing state tort suits against drug manufacturers even after the Food and Drug Administration has approved the drug's warning label would discourage people from using drugs in beneficial ways). But if the claim Professors Brennan, Epstein, and Staudt advance is simply that the Justices sometimes (or even often) respond to consequentialist arguments about the effects of ruling in a particular way, then their article is hardly breaking new ground. See, e.g., STEPHEN BREYER, ACTIVE LIBERTY: INTERPRETING OUR DEMOCRATIC CONSTITUTION 11-12 (2005) (advocating "a broader interpretive approach that places considerable importance upon consequences").

34. See Brennan, Epstein \& Staudt, supra note 2, at 1207 (rejecting the legal model of judicial decisionmaking and concluding that "Justices, in short, will seek to use their decisionmaking power to promote adept policymaking inside the executive and legislative branches of government"). Admittedly, Professors Brennan, Epstein, and Staudt also distance themselves from the attitudinal theory. Id. But because they claim that economic policy preferences outside the law shape judicial decisions, objections that attitudinalists overestimate how often judges deliberately make decisions for nonlegal reasons apply to Brennan, Epstein, and Staudt's model as well. 
assertion implies that the Supreme Court's decisions may be subterfuge. ${ }^{35}$ If Brennan, Epstein, and Staudt are correct, the Court has seriously breached public trust. ${ }^{36}$ No wonder, then, that many of the participants in this Symposium have asked empiricists to tread carefully before making these kinds of claims. As Judge Michael Boudin points out,

[T] call judges' subsequent choices in public policy cases "political" is mere provocation. One can reply blandly that these decisions are political in the sense that they relate to public policy, but few lay readers (or judges) will take it that way. Policy often matters in deciding cases, but it is usually policy attributable to Congress or to public policy reflected in case law, common sense, and the values of the community. Where exactly should judges look when existing law stops short? $?^{37}$

Given the law's long history recognizing that many factors, including environment, can shape judges' decisionmaking, ${ }^{38}$ perhaps a less forceful claim might offer more mutual ground for legal scholars and empiricists going forward.

\section{THE COURT VERSUS THE NEW DEAL}

Professors Brennan, Epstein, and Staudt's second conclusion is that their data debunk conventional wisdom that, prior to the 1937 "switch in time,", the Court was unrelentingly hostile to the Roosevelt administration. ${ }^{40}$ We are skeptical, however, about how much light the data they offer shed on this matter. The constitutional

35. We detect a similar suggestion in Professor Knight's strong distinction between the articulated rationale for a judicial decision and the "actual" bases of decision. See Knight, supra note 8, at 1452 ("[T]he judge's opinion may be unrelated to the actual factors that were influential in deciding the case."). Although we cannot develop the point here, we believe that opinions reflect judges' actual reasons in a considerable majority of cases.

36. See Kahan, supra note 19, at 9 (arguing that his cultural cognition explanation is more palatable than the attitudinal model because it "spare[s] us from the disappointment associated with believing that judicial disagreement stems from self-conscious, and self-consciously concealed, political disregard for the law").

37. Boudin, supra note 10, at 1688. Judge Boudin acknowledges that the judiciary should remain open to learning about its operations, but he suggests that empirical scholars also could show "a little more care in how their conclusions are packaged and explained." Id. at 1689.

38. See supra notes 17-21 and accompanying text.

39. See generally William E. Leuchtenburg, The Supreme Court Reborn: The Constitutional Revolution in the Age of Roosevelt 213-36 (1995) (describing the Court's change of direction in 1937).

40. Brennan, Epstein \& Staudt, supra note 2, at 1196. 
conflict over the regulatory state, which culminated in the 1930s clash between the Court and the New Deal, was fought out primarily in three doctrinal areas: substantive due process or "freedom of contract" challenges to both state and federal regulatory laws, federalism-based challenges to national legislation under the Commerce Clause, ${ }^{42}$ and a much more limited class of nondelegation challenges to early federal administrative agencies. ${ }^{43}$ It is well known that, in other areas, the Supreme Court was often friendly to governmental initiatives. In United States v. Curtiss-Wright Export Corp. ${ }^{44}$ for example, the Supreme Court construed presidential power to act in foreign affairs extremely broadly, brushing aside a nondelegation challenge. The Court sharply distinguished between the national government's domestic and foreign affairs powers, emphasizing that "there are differences between them, and ... these differences are fundamental." ${ }^{45}$ The doctrinal type of case thus matters a great deal when assessing the role of the Court vis-à-vis the political branches. Without some effort to demonstrate that tax cases are typical for the period, it is hard to see how Brennan, Epstein, and Staudt can draw general conclusions from their tax-based dataset.

In any event, we doubt that the "unrelenting hostility" thesis Professors Brennan, Epstein, and Staudt attack is, in fact, the

41. See, e.g., Adkins v. Children's Hosp., 261 U.S. 525, 560-61 (1923) (striking down a minimum wage law as a violation of the "constitutional liberty of contract"); Lochner v. New York, 198 U.S. 45, 60-61 (1905) ("The act is not, within any fair meaning of the term, a health law, but is an illegal interference with the rights of individuals, both employers and employés, to make contracts ....").

42. See, e.g., A.L.A. Schechter Poultry Corp. v. United States, 295 U.S. 495, 548 (1935) (invalidating part of the National Industrial Recovery Act because it violated the boundary between "direct and indirect effects of intrastate transactions upon interstate commerce," a "fundamental" distinction "essential to the maintenance of our constitutional system"); Hammer v. Dagenhart, 247 U.S. 251, 275-76 (1918) (striking down a federal child labor law because it violated the Commerce Clause).

43. See, e.g., Schecter, 295 U.S. at 537-38 ("Congress cannot delegate legislative power to the President to exercise an unfettered discretion to make whatever laws he thinks may be needed or advisable for the rehabilitation and expansion of trade or industry."); Panama Ref. Co. v. Ryan, 293 U.S. 388, 421 (1935) (rejecting another provision of the National Industrial Recovery Act because "Congress manifestly is not permitted to abdicate, or to transfer to others, the essential legislative functions with which it is thus vested").

44. United States v. Curtiss-Wright Exp. Corp., 299 U.S. 304 (1936).

45. Id. at 315; see also Sarah H. Cleveland, Powers Inherent in Sovereignty: Indians, Aliens, Territories, and the Nineteenth Century Origins of Plenary Power over Foreign Affairs, 81 TEX. L. REV. 1, 5 (2002) (arguing that Justice Sutherland's opinion in Curtiss-Wright adopted a vision of federal power in which "the Constitution ... stopped at the water's edge, and the powers of the United States in the external realm derived not from the Constitution, but from concepts of sovereignty shared, recognized, and defined by the community of nations"). 
conventional wisdom in constitutional law. ${ }^{46}$ (Certainly it is not what one of us teaches his first-year students in the subject. ${ }^{47}$ ) Even in the key areas of doctrinal conflict, the Court's record was mixed. One leading casebook notes, for example, that "[a]lthough the Court employed substantive due process on many occasions, it sustained at least as many regulations as it struck down," and that the Court's Lochner-era invalidations "centered primarily, although not exclusively, on labor legislation, the regulation of prices, and restrictions on entry into business." 48 Likewise, in the Commerce Clause cases, the Court combined restrictive decisions like Hammer $v$. Dagenhart $^{49}$ with broader constructions of federal power. ${ }^{50}$ As Professor Barry Cushman has demonstrated, the Court's switch in time represented a choice, in each area, of one already-prominent doctrinal strand over a rival strand, not a categorical change of previously consistent direction. ${ }^{51}$

We are unsure what the statistical analysis of tax cases Professors Brennan, Epstein, and Staudt offer can add to this picture. In addition to the problems we have already noted, simply counting cases cannot assess the qualitative significance of particular decisions. Although Brennan, Epstein, and Staudt find the Court ruled against the government more frequently in these cases prior to 1930, a more doctrinally oriented scholar has observed that, prior to 1934, "[i]n the tax cases and in the commerce cases... the Supreme Court had conducted only occasional and rather limited forays against the

46. Professors Brennan, Epstein, and Staudt cite a number of standard texts indicating that the Supreme Court posed a significant obstacle to the New Deal program. See Brennan, Epstein \& Staudt, supra note 2, at 1223-24 n.74. But none of these sources says that the Court's decisions attacking the New Deal were numerous as a percentage of the Court's overall work product during the period or that its opposition extended to decisions outside a relatively small number of doctrinal categories. The conventional wisdom would have to be categorical indeed to be disproven by an observation that the government won a majority of its tax cases during the relevant period.

47. See Ernest A. Young, The Supreme Court and Constitutional Structure (Oct. 2008) (unpublished manuscript, on file with the Duke Law Journal).

48. Geoffrey R. Stone, louis Michael Seidman, Cass R. Sunstein, Mark V. TUSHNET \& PAMELA S. KARLAN, CONSTITUTIONAL LAW 755-56 (5th ed. 2005).

49. Hammer v. Dagenhart, 247 U.S. 251 (1918).

50. See, e.g., Houston, E. \& W. Tex. Ry. v. United States, 234 U.S. 342, 360 (1914) (upholding the Interstate Commerce Commission's authority to regulate intrastate commerce that substantially affects interstate commerce); see also Coronado Coal Co. v. United Mine Workers, 268 U.S. 295, 310 (1925) (construing the reach of the Antitrust Act broadly); Stafford v. Wallace, 258 U.S. 495, 528 (1922) (upholding the constitutionality of the Packers and Stockyards Act of 1921 under the Commerce Clause).

51. See Barry Cushman, Rethinking the New DeAl Court 45-225 (1998). 
welfare state... [T] he actual negative decisions of importance were few, and the march toward regulation had been at most deflected slightly and, here and there, somewhat delayed." ${ }^{52}$

The Court's confrontation with the New Deal intensified in 1935-1936, however, and this confrontation did extend into the tax realm. In United States $v$. Butler, ${ }^{53}$ the Court struck down a key New Deal law, the Agricultural Adjustment Act (AAA), holding that the act was beyond Congress's taxing-and-spending power because it invaded the reserved powers of the states in the Tenth Amendment. ${ }^{54}$ The Court acknowledged that it was invalidating a critical part of the New Deal. Rejecting the government's argument that the national government had power to tax individual farmers who refused to participate in the AAA's program because of the scope of the economic crisis, the Court explained,

It does not help to declare that local conditions throughout the nation have created a situation of national concern; for this is but to say that whenever there is a widespread similarity of local conditions, Congress may ignore constitutional limitations upon its own powers and usurp those reserved to the states. ${ }^{55}$

Rather than deliberately deferring to Congress and President Roosevelt in 1936, the Court chose-at a critical moment-to undermine the New Deal. Regardless of how the Court performed in individual cases, it seems unlikely that the Justices were deliberately trying to help the political branches in a crisis ${ }^{56}$ just when they were invalidating key legislation.

In its practical significance, a setback like Butler may outweigh five or ten government victories in ordinary tax cases. ${ }^{57}$ Professors Brennan, Epstein, and Staudt offer no metric, however, for assessing the relative significance of individual judicial results. Even within the tax area, their approach thus overlooks important nuances in cases during the period that may challenge their overarching conclusion

52. Robert G. McCloskey, The American Supreme Court 100-01 (5th ed. 2005).

53. United States v. Butler, 297 U.S. 1 (1936).

54. Id. at 74 .

55. Id. at 74-75.

56. See Brennan, Epstein \& Staudt, supra note 2, at 1198 ("[W]hen the Justices believe that the economic crisis is the result of factors largely beyond the control of the government, they will often not sanction federal policymakers but instead seek to work as a team with the other branches of government to remedy the national crisis ....").

57. See LeUCHTENBURG, supra note 39, at 96 (describing the AAA, struck down in Butler, as one of "Roosevelt's two most important recovery programs"). 
that the Justices were voting to shape economic policy by assisting the government's program.

More broadly, Professors Brennan, Epstein, and Staudt's contention that the Court deferred to the political branches during the Great Depression fails to explain the Court's famed and frequent rejection of important pieces of New Deal legislation outside the tax area. After all, Brennan, Epstein, and Staudt purport to have chosen tax cases largely for reasons of convenience, not because they think the Court is uniquely likely to vote to influence economic policy in tax cases but not in other areas. ${ }^{58}$ If their thesis holds, then historical evidence should show the Court trying to aid the government by implementing the political branches' chosen remedies for the Depression across a variety of doctrinal areas, including freedom of contract and the Commerce Clause. But that is hardly what the Court's resistance to the New Deal, which stiffened mid-decade, suggests. In cases like A.L.A. Schechter Poultry Corp. v. United States ${ }^{59}$ Carter v. Carter Coal Co. ${ }^{60}$ and Morehead v. New York ex rel. Tipaldo ${ }^{61}$ the Court struck down or threatened major New Deal initiatives precisely at the time when the Brennan-Epstein-Staudt model predicts that the Court should have supported government policy. ${ }^{62}$ Regardless of how many other cases the government won in this period, it seems unlikely the Court thought that these government victories would overcome the Court's hostile decisions in terms of qualitative importance. The Court's conservative majority surely intended decisions like Schechter and Carter Coal to threaten the New Deal, and it must have expected the Roosevelt administration to perceive them as threats. Does anyone really think that Franklin Roosevelt simply misperceived the Court's behavior

58. See Brennan, Epstein \& Staudt, supra note 2, at 1209 ("We could use several legal contexts to test our theory, but we believe that taxation is an excellent venue for investigating the effects of the economy on judicial behavior ....").

59. A.L.A. Schechter Poultry Corp. v. United States, 295 U.S. 495 (1935).

60. Carter v. Carter Coal Co., 298 U.S. 238 (1936).

61. Morehead v. New York ex rel. Tipaldo, 298 U.S. 587 (1936). Although Tipaldo invalidated state minimum-wage legislation, it revived the doctrine of Adkins v. Children's Hospital, 261 U.S. 525 (1923), which had invalidated a federal minimum wage law, and it was widely perceived as indicating that the Court would employ economic substantive due process to attack national New Deal legislation. See DAvid M. KENNEDy, FreEdom FROM FEAR: THE AMERICAN PEOPLE IN DEPRESSION AND WAR, 1929-1945, at 329-30 (1999).

62. See, e.g., LeUChtenburg, supra note 39, at 215 ("The Supreme Court during these months [in 1935 and 1936] frequently went out of its way to frustrate the Roosevelt administration."). 
when he proposed court packing as a remedy to curb the Court's hostility?

The basic problem is that quantitative analysis that simply counts case results cannot, of itself, refute the established qualitative story concerning the Court and the New Deal. On one hand, Professors Brennan, Epstein, and Staudt have shown that the government won a good many (tax) cases during this period. On the other, however, nothing in the data can deny that the Court became increasingly hostile to the New Deal in high-profile constitutional cases and that these cases amounted to major setbacks for President Roosevelt's program. A macroeconomic model that could predict in advance, or at least explain in hindsight, the overall qualitative drift under certain conditions would be both interesting and useful. But our interlocutors' model does not do that. And absent some method of weighing qualitative importance of cases won and lost, one cannot even confirm the hypothesis that the Court favors the government overall during an economic depression.

We think, moreover, that conventional legal explanations may well resolve apparent contradictions in the Court's results. The major government setbacks we have discussed-for example, Butler, Schechter, Carter Coal-were all cases about the constitutional boundaries of government power. We suspect that most of the cases in the Brennan-Epstein-Staudt dataset, however, involve the application of the tax laws to cases that all concede come within the constitutional purview of governmental authority. These cases may involve difficult questions of statutory construction or the application of law to fact, but not outright challenges to the legitimacy of government power. Perhaps the Court saw the case for deference to governmental actors as more compelling when government officials were acting within their constitutional authority but wished to maintain a more vigilant posture when policing the boundaries of that constitutional authority. This stance would be consistent, for example, with the "constitutional fact" doctrine announced in the Court's earliest encounter with administrative adjudication. ${ }^{63}$ It would also be consistent with later tendencies to defer to agency actions pursuant to statutory authority but to review constitutional claims de novo. ${ }^{64}$ One

63. Crowell v. Benson, 285 U.S. 22, 51-61 (1932).

64. See, e.g., Adrian Vermeule, Our Schmittian Administrative Law, 122 HARV. L. REV. 1095, 1115 (2009) ("[E]ven in cases where agency action is otherwise committed to agency discretion by law as to statutory claims, the Court has allowed review of constitutional claims, 
would have to investigate the tax cases in the dataset to verify this hypothesis. But the Brennan-Epstein-Staudt hypothesis standing alone cannot account for the pattern of major government losses in high-profile constitutional cases like Butler or Schechter, notwithstanding the Court's overall tendency to rule in favor of the government. Our conventional legal explanation may well account for this tendency.

In sum, legal analysis remains useful to understanding the nuances of Court behavior. Legal scholars first demonstrated that the Court was neither uniformly hostile nor uniformly positive toward the Roosevelt administration even prior to the 1937 switch in time. Indeed, legal scholarship provides a more nuanced view of the Court's decisions during the New Deal than Professors Brennan, Epstein, and Staudt have acknowledged, and their failure to recognize other scholars' findings may explain some of the legal academy's skepticism toward the empirical project. Additionally, law may actually explain why the Court tended to favor the government during the 1930s yet voted against the New Deal in important cases. Unless empiricists are open to considering legal explanations for empirical findings, they may overlook new areas of research.

\section{EXPLAINING AND PREDICTING}

Finally, Professors Brennan, Epstein, and Staudt claim that their findings "help explain Supreme Court votes" and "forecast upcoming votes in the context of the nation's serious economic decline." ${ }^{, 65}$ To explain and forecast the Court's decisions, however, Brennan, Epstein, and Staudt would need to offer a more fine-grained account of why they are observing this trend in tax cases and how macroeconomic factors influence judicial decisionmaking. Without considerably more information concerning how the Court responds to macroeconomic stimuli, it is difficult either to explain or predict its behavior.

The first problem concerns the divide between the two quite different types of responses to macroeconomic factors that Professors Brennan, Epstein, and Staudt hypothesize. In "ordinary" times, they suggest, the Court rewards the government for good economic

professedly in order to avoid the serious constitutional questions that would arise if judicial review of constitutional claims were unavailable.").

65. Brennan, Epstein \& Staudt, supra note 2, at 1196. 
performance and punishes it during downturns. ${ }^{66}$ In times of serious economic crisis, on the other hand, the Court bands together with the political branches to help get the economy back on its feet. ${ }^{67}$ But this dualist approach to economic stimuli presumes that the Justices-few of whom are economic experts-can accurately differentiate between ordinary downturns and serious crises. Even economic experts cannot tell, for example, when the nation entered a recession in 2008, how serious the recession is, and when it will end. ${ }^{68}$ Should the Justices begin to punish the government or defer to it? In the absence of readily applicable criteria to determine which of the two opposing courses to follow, the import of macroeconomic factors for judicial decisionmaking is simply indeterminate.

We also think that Professors Brennan, Epstein, and Staudt need to defend their assumption that Justices respond to economic stimuli in the same way that voters do. A voter choosing a candidate is in a very different position than a Justice considering whether to invalidate a government policy. When voters decide whether to continue supporting the incumbent, their alternative is to put someone else in office who may have a better idea. The Court cannot do the latter; it generally must vote up or down on a government policy, having only extremely limited opportunities to replace that policy with some preferred alternative. It is therefore unclear why the Justices would think that merely punishing incumbent leaderswithout replacing them with someone else-would help the economy. Throwing a wrench into the only available policy may be even worse. Without further analysis, the simple hypothesis that Justices act like voters is unpersuasive.

This second objection drives at a larger problem with importing political science scholarship into legal academia-the risk that nonlegal experts may import preconceived expectations as well. Professors Brennan, Epstein, and Staudt begin by hypothesizing that

66. Id. at 1198 .

67. Id.

68. See Edmund L. Andrews, Recession Began Last December, Economists Say, N.Y. Times, Dec. 2, 2008, at A1; Neil Irwin, Recession Could End This Year, Fed Chief Says, WASH. PosT, Feb. 25, 2009, at A1. The same has been true of past economic crises, including the Great Depression. See, e.g., KenNedy, supra note 61, at 65 ("Down to the last weeks of 1930, Americans could still plausibly assume that they were caught up in yet another of the routine business-cycle downswings that periodically afflicted their traditionally boom-and-bust economy."); id. at 59 (noting that "most Americans in 1930 saw these developments less clearly than did later analysts" and that the drop in GNP and rise in unemployment had actually been greater during the 1921 recession than in the initial stages of the Great Depression). 
Justices act like voters. ${ }^{69}$ They appear to have developed their core thesis-that the Justices vote to punish or reward the political branches depending on economic conditions-from a behavior model designed specifically for voters. ${ }^{70}$ But voters have a fundamentally different responsibility than Justices. At a minimum, our interlocutors have not explained or defended the assumption that voters and Justices behave similarly.

A statistical correlation between economic performance and case results cannot justify their assumption. As Professor Frank Cross has noted, readers should avoid reading too much into statistical correlations-showing a correlation does not prove variables are necessarily related. ${ }^{71}$ Moreover, analysis of Professors Brennan, Epstein, and Staudt's general data cannot exclude certain important alternative possibilities. We have already noted that economic factors are legally relevant in important classes of cases. Another possibility arises from the voter model itself: if political support for the government tends to track economic performance, then how do we know that economic performance has any direct effect on the courts? After all, judges might simply be responding to the government's political support, which in turn responds to the economy. Absent some way to control for the government's level of political support, Brennan, Epstein, and Staudt may simply have confirmed Mr. Dooley's original assertion that the Supreme Court follows the election returns. $^{72}$

Perhaps one could respond that the Brennan-Epstein-Staudt model is only preliminary. But this literature has a penchant for throwing out "preliminary" explanations that, without much refinement, soon become conventional wisdom in political science circles. $^{73}$ This tendency is particularly troubling when political science scholars purport to "discover" the actual reasons judges decide cases, which judges then successfully conceal by filling opinions with legal

\footnotetext{
69. Brennan, Epstein \& Staudt, supra note 2, at 1194.

70. See id. at 1195 .

71. Frank B. Cross, Decision Making IN the U.S. Courts of Appeals 4 (2007); see also Harry T. Edwards \& Michael A. Livermore, Pitfalls of Empirical Studies that Attempt to Understand the Factors Affecting Appellate Decisionmaking, 58 DUKE L.J. (forthcoming 2009) (manuscript at 13-14) (cautioning against adopting empirical conclusions uncritically).

72. See supra text accompanying note 1 .

73. See Frank B. Cross, The Justices of Strategy, 48 DukE L.J. 511, 538 (1998) (book review) (calling Professors Epstein and Knight's judicial behavioral model in The Choices Justice Make "one-dimensional" but conceding that "they are presenting an initial model"). Ten years have passed without a great deal of refinement in key aspects of this strategic model.
} 
justifications. ${ }^{74}$ These often-undersupported claims can enter the public consciousness uncritically, ${ }^{75}$ undermining courts' legitimacy. These claims also risk misleading participants in the legal system, many of whom lack the statistical proficiency to properly evaluate empirical findings. ${ }^{76}$ Because lawyers and the general public may misunderstand the limits of "preliminary" findings, perhaps empiricists should avoid reaching for bold explanations of early data. Legal scholars have long contended that other explanations soften or explain empiricists' claims that judges vote by ideology or policy preference. $^{77}$ The most fruitful avenues for empirical research, we suspect, will involve more circumscribed research questions at the intersection of political science and legal explanations.

A third problem is that the Brennan-Epstein-Staudt account is simultaneously too general and too narrow. It is too general in the sense that, without a more fine-grained understanding of why economic factors influence Justices in some cases but not others, the model cannot predict (or explain) results in particular disputes. Butler and similar cases demonstrate that, even in times when the overall data show the Court favoring the government, the government can still lose-and lose big - in individual cases. So if one wants to explain or predict individual cases, then one needs to better determine when Justices defer to government policy based on something more specific than the Justices' general self-interest in overall economic performance. We are not sure that our interlocutors can offer that, and we have already suggested that traditional types of legal explanations may better explain individual decisions.

Our interlocutors' account is too narrow, however, in that its empirical demonstration focuses only on tax cases. Although

74. See, e.g., SEGAL \& SPAETH, supra note 7, at 53 ("[W]e argue that the legal model and its components serve only to rationalize the Court's decisions and to cloak the reality of the Court's decision-making process."); Knight, supra note 8, at 1542 (“[T]he judge's opinion may be unrelated to the actual factors that were influential in deciding the case.").

75. See, e.g., Linda Greenhouse, At the Court, Dissent over States' Rights Is Now War, N.Y. TIMES, June 9, 2002, at C3 (suggesting that the attitudinal model explains Justices' decisions in federalism cases without considering arguments against the validity of the model).

76. See Edwards \& Livermore, supra note 71 (manuscript at 14) ("[M]ost law students and members of the legal profession are not trained in the nuances and limits of empirical analysis.").

77. E.g., Frank B. Cross, Political Science and the New Legal Realism: A Case of Unfortunate Interdisciplinary Ignorance, 92 NW. U. L. REV. 251, 279-309 (1997) (critiquing the attitudinal model and concluding that it "clearly contains some truth" but "offers only an incomplete explanation of legal decisionmaking" and "[t]he exaggerated claims of some proponents are insupportable in the face of closer scrutiny"). 
empiricists may struggle to document it statistically, it is hard to rule out the possibility that judicial deference to government actors varies profoundly across subject areas. For instance, conventional wisdom holds that the contemporary judiciary defers more to some executive agencies than to others, based on differential evaluations of the competence and integrity of those agencies; more formally, existing doctrine prescribes varying levels of deference depending on, for example, whether an agency has been delegated legislative rulemaking authority. ${ }^{78}$ If so, this fact would seriously undermine how well scholars can generalize from findings based on tax cases. To predict the consequences of the current economic crisis on judicial decisionmaking, then, we would need not only some overall measure of deference but some way to understand how that plays out in individual regulatory areas.

It is possible that more fine-grained empirical studies of casesas Professor Knight has proposed ${ }^{79}$ - could resolve these questions. Legal scholars can assist that effort by identifying gaps in doctrinal explanations that more quantitative approaches might fill. From the other direction, empirical scholars like Professors Brennan, Epstein, and Staudt might identify gaps in the explanatory power of their data that could, in turn, benefit from legal analysis. Along these lines, we conclude by offering some law-generated suggestions for refining the empirical investigation of macroeconomic influences on judicial decisionmaking.

\section{QUESTIONS ABOUT THE RESEARCH DESIGN}

In this last Part, we suggest some ways to build on and modify Professors Brennan, Epstein, and Staudt's project. These suggestions are internal in the sense that they accept the basic thrust of the project but offer some ways the study could be refined.

We have already suggested that tax cases may not be all that representative of the dynamic between the Court and the political

78. See, e.g., United States v. Mead Corp., 533 U.S. 218, 233-38 (2001). See generally William N. Eskridge, Jr., \& Lauren E. Baer, The Continuum of Deference: Supreme Court Treatment of Agency Statutory Interpretations from Chevron to Hamdan, 96 GEO. L.J. 1083 (2008) (describing the Court's different approaches to deferring to administrative agency actions).

79. See Knight, supra note 8, at 1548 (calling on empirical scholars to study the substantive content of law). 
branches. ${ }^{80}$ A related difficulty concerns the relevance of particular tax cases to the Brennan-Epstein-Staudt thesis. That thesis could have two distinct versions: In one version, the Justices rule on cases to judge and attempt to influence the current administration's economic policy. In the other, the Court generally judges the state of the economy and then punishes the political branches for bad economic management by reflexively voting against the government in cases across the board. If Professors Brennan, Epstein, and Staudt are advancing the latter argument, then it makes sense to count all tax cases in the dataset. But if their position is, in fact, closer to the first alternative, then we would think one should count only those tax cases that actually reflect the current administration's economic policy. ${ }^{81}$ A more focused study would exclude, for example, many tax cases interpreting older provisions enacted under previous administrations. In any event, Brennan, Epstein, and Staudt ought to explain more explicitly which tax cases are relevant to their thesis and why-preferably by clarifying the relationship between particular cases and the policy of the incumbent administration.

A second issue concerns the impact of time-lag problems on interpretations of judicial results. Our friends from The University of North Carolina at Chapel Hill have addressed this issue at greater length in their response in this Symposium, ${ }^{82}$ so we only note the problem briefly. Two potentially relevant lags exist: the time that elapses from enactment of a statute or implementation of a policy to any legal challenge to that statute or policy and the lag from the initial challenge to the Supreme Court's decision of the case. ${ }^{83}$

80. We are also nervous about inferring much from tax cases decided immediately after Congress enacted the first constitutional federal income tax in 1913. Act of Oct. 3, 1913, ch. 16, $\S$ II, 38 Stat. 114, 166-81. One would expect Court decisions to fluctuate for some time while the Court sorted out the meaning of the new statute.

81. It is not clear that the Roosevelt administration focused much on tax reform other than the tax provisions connected to the Social Security Act that the Court struck down in Butler. We are indebted to our colleagues Larry Zelenak and Richard Schmalbeck on this point.

82. See Scott Baker, Adam Feibelman \& William P. Marshall, Response, Justices as Economic Fixers: A Response to A Macrotheory of the Court, 58 DUKE L.J. 1627, 1637-38 (2009). Professor Young thinks that "friends" is a particularly generous appellation given that this issue is going to press in the midst of the NCAA basketball tournament. Ms. Blondel agrees, but only because Carolina beat Notre Dame in football in 2008.

83. See, e.g., United States v. Cambridge Loan \& Bldg. Co., 278 U.S. 55, 55-60 (1928) (reporting that the Commissioner of Internal Revenue assessed taxes against the bank on September 18, 1924, when Professors Brennan, Epstein, and Staudt show the economy was beginning an upswing, but that the Court decided the case in November 1928, after the economy had peaked, bottomed, and begun to improve); Supplee-Biddle Hardware Co. v. United States, 
Professors Brennan, Epstein, and Staudt do not appear to address which time is relevant for pegging a litigated dispute to the government's larger economic policy and its macroeconomic result. Does the Court evaluate the competence of the government that enacted a statute by considering the economic climate at the time it was enacted? Or does the Court simply kick a government that it perceives to be incompetent (because of economic performance) at the time of decision, regardless of whether it was the same government or same conditions when the statute was originally enacted? This confusion is particularly a problem during the early period of the Brennan-Epstein-Staudt study because the economy was fluctuating in relatively short-term cycles and the lifecycle of some cases likely spanned upturns and downturns. ${ }^{84}$

Our third question arises from the assertion that the Justices consciously seek to influence macroeconomic policy. ${ }^{85}$ Professors Brennan, Epstein, and Staudt do not appear to suggest that Supreme Court decisions themselves affect national economic performance. But why not? It seems at least possible that the Justices could realistically expect to influence economic performance directly in at least some cases. It would be interesting to know, for example, what the New York Stock Exchange did on "Black Monday," May 27, 1935, when Schechter, Louisville Joint Stock Land Bank v. Radford ${ }^{86}$ (which struck down a mortgage moratorium), ${ }^{87}$ and Humphrey's Executor v. United States ${ }^{88}$ all came down on the same day. ${ }^{89}$ If our

58 Ct. Cl. 343, 346 (1923) (reporting that the government assessed taxes in July 1922, during an expansion, but the Court decided the case in May 1924, after the economy had peaked and begun to sink), aff'd, 265 U.S. 189 (1924).

84. We also note that tax cases may be unrepresentative because, in the early period of Professors Brennan, Epstein, and Staudt's study, tax cases came to the Court quicker than other sorts of cases because of expedited review provisions. In the modern era, the Court's discretionary certiorari policy would also complicate this problem because it encourages the Court not to take the first case from a court of appeals raising a given issue, but rather to wait until a circuit split develops.

85. For a discussion of this assertion, see supra notes 14-16 and accompanying text.

86. Louisville Joint Stock Land Bank v. Radford, 295 U.S. 555 (1935).

87. Id. at 601-02.

88. Humphrey's Ex'r v. United States, 295 U.S. 602 (1935). Although Humphrey's Executor upheld the federal law in question-which allowed Congress to limit the president's authority to remove a commissioner of an independent agency-against constitutional challenge, id. at 631-32, the Court's decision was widely perceived as a challenge to the Roosevelt administration, which had sought broader control of the national administrative bureaucracy, see LEUCHTENBERG, supra note 39, at 78 (reporting that Humphrey's Executor "stunned the Roosevelt Administration"); see also Christopher S. Yoo, Steven G. Calabresi \& Laurence D. Nee, The Unitary Executive During the Third Half-Century, 1889-1945, 80 NoTRE 
interlocutors are right about Justices' incentives to influence economic performance, one might expect the Justices to attempt to do so directly as well as indirectly. If we see no such attempts, on the other hand, we might question the salience of economic motivations in judicial decisionmaking.

Finally, we note some important structural considerations arising from the complex institutional environment that the U.S. Supreme Court inhabits. Initially, the Supreme Court is not the only court in the system. Do lower court judges respond to macroeconomic factors in the same way as the Supreme Court? This point is important, in part, because the behavior of the lower courts affect the ways in which issues get on the Supreme Court's agenda. ${ }^{90}$ More importantly, cases in the Supreme Court are highly unrepresentative of the run of litigation. If Professors Brennan, Epstein, and Staudt want to infer anything about judicial behavior generally, they must broaden their focus to include a more typical dataset of judicial results. ${ }^{91}$

Moreover, the federal government is not the only government. The Supreme Court has a relationship with two sets of economic policymakers - the national government and the states. One might even expect the Court to have been more concerned with state cases, especially in the early period of the study, given that state legislatures were primary regulators at that point in history. State governments also affect the economy, and many, many state tax cases existincluding constitutional challenges to those taxes under the dormant Commerce Clause and other doctrines. The Supreme Court decided a number of these cases during the period relevant to the BrennanEpstein-Staudt study, ${ }^{92}$ and it would surely be relevant to know whether the results in those cases conform to the "macrotheory"

DAME L. REV. 1, 84-88 (2004) (reciting the history of Humphrey's Executor and concluding that it "represents another example of the hostility towards the Roosevelt Administration exhibited by many Supreme Court decisions of that period").

89. See KENNEDY, supra note 61, at 328.

90. See, e.g., United States v. Lopez, 514 U.S. 549, 552 (1995) (explaining that the Court granted certiorari in Lopez because the Fifth Circuit had taken the initiative to invalidate a federal statute on Commerce Clause grounds).

91. See Edwards \& Livermore, supra note 71 (manuscript at 29) (critiquing one empirical dataset because it excludes unpublished decisions, many of which are unanimous opinions involving settled legal issues); David F. Levi, Autocrat of the Armchair, 58 DuKE L.J. 1791, 1800-02 (2009) (book review) (critiquing Judge Posner's book, How Judges Think, because Posner fails to consider how judges act in typical cases).

92. E.g., McLeod v. J.E. Dilworth Co., 322 U.S. 327, 330-31 (1944) (dormant Commerce Clause); Di Santo v. Pennsylvania, 273 U.S. 34, 37 (1927) (same). 
tested on the federal side. ${ }^{93}$ We do not seek to answer, or even explore, these questions in this Response. But we think that the fascinating model that Professors Brennan, Epstein, and Staudt have advanced would benefit from considering the complex institutional environment in which the Court operates.

\section{CONCLUSION}

This Symposium challenges empirical scholars, legal academics, and judges to discuss why empirical literature on judicial behavior and more conventional legal discourse so often seem like ships passing in the night. Professors Brennan, Epstein, and Staudt's article suggests both why legal experts remain skeptical and how empiricists could provide more useful data. As several participants note, many empiricists antagonize legal professionals by charging that judges make decisions for reasons other than the law. ${ }^{94}$ Brennan, Epstein, and Staudt similarly dismiss the legal approach. ${ }^{95}$ But their data do not substantiate their most provocative claim-that the Justices consciously seek to influence economic policy-and their model remains largely silent on why the Justices decide particular cases the way they do. Nor have our interlocutors adequately defended their exclusive focus on tax cases or considered alternative explanations for a correlation between judicial results and economic performance. Such performance, after all, may be legally relevant or may affect the valence and weight of more traditional political pressures on the Court.

These difficulties in the Brennan-Epstein-Staudt study raise a more basic problem with much of the empirical judicial behavior literature. Few legal experts or judges are empiricists. When they review an empirical paper, they want to know what the empiricist has concluded from the data. Yet much empirical literature proposes possible explanations for empirical data without carefully considering a study's implications. This premium placed on bold and seemingly categorical conclusions may be a rational response to publication

93. See generally Stephen Gardbaum, New Deal Constitutionalism and the Unshackling of the States, 64 U. CHI. L. REV. 483 (1997) (discussing the Court's approach to dormant Commerce Clause cases concerning state taxation and regulation during the Lochner and New Deal periods).

94. E.g., Boudin, supra note 10, at 1687 ("Figuring out why judges decide cases the way they do is a worthy enterprise; not so scoring judicial results as 'political."').

95. Brennan, Epstein \& Staudt, supra note 2, at 1204. 
imperatives in academia, but to lawyers, it may suggest indifference to legitimate explanations for empirical data. Additionally, many empiricists, including Professors Brennan, Epstein, and Staudt, seem to default to less plausible explanations for judicial behavior-for example, that judges are voting their political viewpoints or trying to affect the economy. These conclusions seem unlikely to lawyers and inaccurate-even offensive-to judges. Because empiricists too often fail to heed these objections, they appear entrenched, and the two sides fail to communicate.

This breakdown is unfortunate, because we believe that empirical approaches have great promise in enhancing our understanding of the law and judging. Professors Brennan, Epstein, and Staudt have observed an interesting trend in their study; in particular, they have sharpened and provided at least some statistical confirmation for the general intuition among legal professionals that the more general state of the world affects the way courts decide particular cases. The evident success of this conference suggests that political scientists and more traditional legal scholars can work together to refine the analysis of these and similar tendencies. Both disciplines would benefit from that sort of nuanced and respectful collaboration. 